\title{
Impairment of translation in neurons as a putative causative factor for autism
}

\author{
Eugenia Poliakov ${ }^{1}$ Eugene V Koonin ${ }^{2^{*}}$ and Igor B Rogozin $2^{2 *}$
}

\begin{abstract}
Background: A dramatic increase in the prevalence of autism and Autistic Spectrum Disorders (ASD) has been observed over the last two decades in USA, Europe and Asia. Given the accumulating data on the possible role of translation in the etiology of ASD, we analyzed potential effects of rare synonymous substitutions associated with ASD on mRNA stability, splicing enhancers and silencers, and codon usage.

Presentation of the hypothesis: We hypothesize that subtle impairment of translation, resulting in dosage imbalance of neuron-specific proteins, contributes to the etiology of ASD synergistically with environmental neurotoxins.
\end{abstract}

Testing the hypothesis: A statistically significant shift from optimal to suboptimal codons caused by rare synonymous substitutions associated with ASD was detected whereas no effect on other analyzed characteristics of transcripts was identified. This result suggests that the impact of rare codons on the translation of genes involved in neuron development, even if slight in magnitude, could contribute to the pathogenesis of ASD in the presence of an aggressive chemical background. This hypothesis could be tested by further analysis of ASD-associated mutations, direct biochemical characterization of their effects, and assessment of in vivo effects on animal models.

Implications of the hypothesis: It seems likely that the synergistic action of environmental hazards with genetic variations that in themselves have limited or no deleterious effects but are potentiated by the environmental factors is a general principle that underlies the alarming increase in the ASD prevalence.

Reviewers: This article was reviewed by Andrey Rzhetsky, Neil R. Smalheiser, and Shamil R. Sunyaev.

Keywords: Synonymous mutations, Single nucleotide polymorphism, Codon usage, Splicing enhancer, Splicing silencer, mRNA secondary structure, Transcription factor binding, Neurotoxin

\section{Background}

Autism prevalence in USA increased from 1 in 2,000 in 1970 to 1 in 68 in 2010 [1]. The CDC estimate for Autistic Spectrum Disorders (ASD) among school aged children (8 years) has increased by 78\% during 2002-2008 (from 1 in 156 to 1 in 88) [2]. A major increase in the prevalence of autism was observed over the last two decades also in Asia and Europe [3].

The causes of such an apparent explosion of ASD are a subject of intense debate. Several recent studies examined the rate of de novo mutations in autistic children and their possible importance in the etiology of ASD

\footnotetext{
*Correspondence: koonin@ncbi.nlm.nih.gov; rogozin@ncbi.nlm.nih.gov

${ }^{2}$ National Center for Biotechnology Information, National Library of Medicine, National Institutes of Health, Bethesda, MD, USA

Full list of author information is available at the end of the article
}

[4-7]. Comparison of ASD-affected individuals and their parents and/or unaffected siblings revealed modest but significant excess of de novo mutations in ASD, particularly in genes that are specifically expressed in the brain [4]. These findings imply a substantial genetic component in the etiology of ASD but fail to shed light on the recent dramatic increase in the prevalence of autistic disorders. In general, the rate of mutations linked to classic Mendelian and complex diseases does not seem to have significantly increased within the relevant time span [8-10]. For example, the rate of de novo mutations associated with Huntington's disease has been estimated at steady $8-10 \%$ of all cases over the last decade $[11,12]$. Congruent with this observation, no obvious increase in the incidence of common diseases with a major genetic component, e.g. schizophrenia, haemophilia A or cystic 
fibrosis, has been detected over the last 50 years [13-15]. Thus, germline mutations alone hardly can explain the recent explosion of autism [16]. Another potential factor, change in diagnostic criteria, such as inclusion of milder cases, might explain at best approximately $25 \%$ of the observed increase in ASD incidence [17-20].

By exclusion, it has been proposed that environmental factors including chemicals and microbes could be the primary culprits in the ASD surge [3,18,21-23]. Recent twin studies have shown that susceptibility to ASD has moderate heritability (38\%) and a substantial shared twin environmental component (58\%) [24]. Early twin studies had estimated the heritability of autism to be as high as 90 percent, due to much lower estimates of concordance both members of a twin pair having the disorder - in fraternal twins [25-28]. New studies found the concordance among fraternal twins to be four to five fold higher $[24,29]$. Such a dramatic difference could be explained by smaller sample size in previous twin studies and/or a genuine drop in heritability caused by additional environmental factors that became involved in the etiology of autism in the last twenty years [3].

The changes in environmental factors that occurred during the last two decades have been substantial and numerous. The primary suspects so far are mercury [23], agricultural pesticides [30], air pollutants and solvents $[31,32]$, proximity of maternal residence at the time of delivery to freeways [33], toxins present in plastic and treatment of mothers with selective serotonin reuptake inhibitors, thalidomide, valproic acid and misoprostol [34-36]. However, none of these environmental factors has been firmly established as a contributor to the ASD surge [37].

\section{Presentation of the hypothesis}

Recently, it has been shown that mutations in translational repressors FMRP, TSC1/2 and PTEN [38,39] as well as de novo disruptions of FRMP-regulated genes [7] are associated with ASD, suggesting that defects in translation repression could be a causative factor. Given the accumulating data on the possible role of translation in the etiology of ASD, we analyzed rare synonymous substitutions linked to disorders of the ASD spectrum (delineated from rare gene variations, see below for more details) because these mutations could directly reflect selection at the levels of transcription and/or translation [40]. We assessed potential impact of ASD-associated synonymous substitutions on mRNA stability, splicing enhancers/silencers and codon usage (see below for more details). The results indicate a statistically significant shift in codon usage associated with ASD: a substantial majority of rare synonymous variants change an optimal codon to a sub-optimal one. We hypothesize that subtle impairment of translation resulting from the codon usage shift contributes to the ASD surge through interaction with increasingly used neurotoxic compounds.

\section{Testing the hypothesis}

\section{Features of synonymous variants associated with ASD}

Rare synonymous variations in human genes associated with ASD (the AV set) were selected from the AutDB database [41] and from a set of rare synonymous variations unique to ASD patients that was compiled by Kelleher and co-workers from the AGRE database [42] (Table 1). These variations were polarized under the assumption that a rare variant implicated in ASD is a derived state whereas the alternative common allele is the ancestral state $[41,42]$. Altogether, 87 synonymous AVs in 19 genes were used for further analysis (Additional file 1). We also reconstructed a set of fixed synonymous substitutions for the same set of human genes (Table 1) using multiple alignments of orthologs from humans, chimp and gorilla. For each gene, we compared triplets of species including two sister species (human and chimp) and an outgroup (gorilla). A substitution was assumed to have occurred in the human lineage if the nucleotides in the chimp lineage and in the gorilla outgroup were identical but differed from the nucleotide in the human lineage. The use of parsimony is justified in this case because the distances between the three species of great apes are short [43]. We additionally analyzed common synonymous single nucleotide polymorphisms (SNPs) from the dbSNP database for the same group of genes (Table 1), a set of substitutions that is expected to be strongly enriched for neutral or nearly neutral variants [44]. These common SNPs were polarized using chimp/ gorilla as an outgroup. Furthermore, we examined 99 recently identified de novo synonymous mutations in ASD patients [6,7]. The vast majority of these mutations are unlikely to cause any functional consequences $[6,7,45]$ and accordingly these mutations were used as an additional control.

We compared the properties of the AV to those of the other mutations (Table 2). The AV are enriched in $\mathrm{C}: \mathrm{G}>\mathrm{T}$ :A transitions (Table 2) but the difference from the set of reconstructed mutations, common SNPs and de novo mutations was not significant [46] (Table 2). The frequency of mutations in the $\mathrm{CpG}$ context is higher in the AV set (48\%) compared to the set of reconstructed mutations (25\%), and this difference was statistically significant after correction for multiple comparisons (Table 2). The excess of mutations in CpG sites might reflect subtle differences in the methylation pattern between the AVs and the reconstructed mutation group although problems with the parsimony reconstruction, such as excess of multiple parallel mutations in CpG codons in chimp and gorilla, cannot be ruled out. No significant differences in the $\mathrm{CpG}$ site mutations were observed 
Table 1 The 19 genes with ASD-associated rare synonymous variations

\begin{tabular}{|c|c|c|c|c|c|}
\hline Gene & $\begin{array}{l}\text { Source } \\
\text { database }\end{array}$ & GenBank protein $\mathrm{Gl} /$ brief description & $\begin{array}{l}\text { \# rare synonymous } \\
\text { variants (AVs) }\end{array}$ & $\begin{array}{c}\text { \# reconstructed } \\
\text { synonymous mutations }\end{array}$ & $\begin{array}{c}\text { \# common } \\
\text { synonymous SNPs }\end{array}$ \\
\hline AUTS2 & AutDB & 17225457/autism-related protein 1 & 1 & 2 & 2 \\
\hline CADPS2 & AutDB & 148839294/calcium-dependent secretion activator 2 & 2 & 5 & 3 \\
\hline FOXP2 & AutDB & 298566291/forkhead box protein P2 & 1 & 4 & 2 \\
\hline FMR1 & AutDB & fragile $X$ mental retardation 1 & 1 & 4 & 3 \\
\hline GRM1 & AGRE & 166999098/metabotropic glutamate receptor 1 & 4 & 8 & 5 \\
\hline GRM5 & AGRE & 4504143/metabotropic glutamate receptor 5 & 7 & 3 & 5 \\
\hline HRAS & AGRE & 34222246/GTPase HRas & 1 & 0 & 1 \\
\hline MAP2K1 & AGRE & $\begin{array}{l}5579478 / \text { dual specificity mitogen-activated protein } \\
\text { kinase } 1\end{array}$ & 1 & 0 & 1 \\
\hline MAP2K2 & AGRE & $\begin{array}{l}\text { 13489054/dual specificity mitogen-activated protein } \\
\text { kinase } 2\end{array}$ & 3 & 4 & 4 \\
\hline MECP2 & AutDB & 1708973/Methyl-CpG-binding protein 2 & 9 & 2 & 1 \\
\hline NLGN3 & AutDB & 262359971/neuroligin-3 & 1 & 0 & 1 \\
\hline NRXN1 & AutDB & 154813843/neuronal cell surface protein NRXN1-a & 5 & 10 & 2 \\
\hline PIK3CA & AGRE & $\begin{array}{l}\text { 54792082/phosphatidylinositol 4,5-bisphosphate 3-kinase } \\
\text { catalytic subunit }\end{array}$ & 4 & 2 & 3 \\
\hline RBFOX1 & AutDB & 22538409/RNA binding protein fox-1 homolog 1 & 3 & 6 & 1 \\
\hline SHANK2 & AutDB & $\begin{array}{l}254763402 / \mathrm{SH} 3 \text { and multiple ankyrin repeat domains } \\
\text { protein } 2\end{array}$ & 8 & 6 & 3 \\
\hline SHANK3 & $\begin{array}{l}\text { AutDB, } \\
\text { AGRE }\end{array}$ & $\begin{array}{l}\text { 380748963/SH3 and multiple ankyrin repeat domains } \\
\text { protein } 3\end{array}$ & 27 & 4 & 9 \\
\hline TSC1 & AGRE & 4507693/tuberous sclerosis gene TSC1 & 3 & 2 & 2 \\
\hline TSC2 & AGRE & 116256352/tuberous sclerosis 2 protein & 5 & 11 & 8 \\
\hline UBE3A & AGRE & 19718764/ubiquitin-protein ligase E3A & 1 & 3 & 5 \\
\hline
\end{tabular}

between the AV set and de novo synonymous mutations or common SNPs (Table 2). Regardless of its biological relevance, the observed excess of mutations in the $\mathrm{CpG}$ dinucleotides and obvious biases in substitution patterns (Table 2) should not be ignored in any analysis of AVs. These biases were taken into account in the analysis of codon usage, splicing enhancers/silencers and free energy as described below.

For the analysis of the changes in codon usage, we used multiple sources of codon frequencies in brain-specific genes (denoted here as F). The codon frequencies were inferred from two sets of brain-specific genes that were

Table 2 Features of the analyzed synonymous variations/mutations

\begin{tabular}{|c|c|c|c|c|}
\hline & $\begin{array}{l}\text { 1. Rare variations from } \\
\text { AutDB/AGRE (AVs) }\end{array}$ & $\begin{array}{l}\text { 2. Reconstructed } \\
\text { mutations }\end{array}$ & 3. Common SNPs & $\begin{array}{l}\text { 4. De novo } \\
\text { mutations }\end{array}$ \\
\hline$C: G>T: A$ & 64 & 44 & 34 & 66 \\
\hline$C: G>A: T$ & 7 & 6 & 8 & 6 \\
\hline$C: G>G: C$ & 4 & 3 & 6 & 6 \\
\hline $\mathrm{T}: \mathrm{A}>\mathrm{C}: \mathrm{G}$ & 10 & 20 & 9 & 16 \\
\hline $\mathrm{T}: \mathrm{A}>\mathrm{G}: \mathrm{C}$ & 1 & 3 & 3 & 3 \\
\hline$T: A>A: T$ & 1 & 3 & 1 & 2 \\
\hline \multicolumn{5}{|c|}{$P_{M C X 2}=0.390, P_{c t c x 2}=0.378, P_{Z d}=0.464$} \\
\hline Mutations in CpG's (total \#mutations) & 42 (out of 87 ) & 20 (out of 79) & 24 (out of 61) & 42 (out of 99) \\
\hline \multicolumn{2}{|c|}{$\mathrm{P}_{\text {Fisher }}$ for two columns (C's) } & C1 vs. C2 & C1 vs. C3 & C1 vs. C4 \\
\hline & & 0.002 & 0.316 & 0.462 \\
\hline
\end{tabular}

A Monte Carlo modification of the Pearson $x_{2}$ test (MCX2) of spectra homogeneity, CTC $X 2$ and Zd measures were used for comparison of mutation frequencies as implemented in the COLLAPSE program [46]. Two-tailed Fisher exact test was used to compare frequencies of substitutions in CpG sites. 
delineated using expressed sequence tags [47] and microarray data $[48,49]$. Codon frequencies were also calculated for the set of 19 AV genes (Table 1). The shift in codon usage $\left(S_{H}\right)$ between common allele variants $(\mathrm{C}-\mathrm{CV})$ and polarized rare synonymous variants $(\mathrm{C}-\mathrm{AV})$ was calculated using the equation:

$$
\mathrm{S}_{\mathrm{H}}=\sum_{\mathrm{i}=1}^{\mathrm{N}} \frac{\left(\mathrm{F}^{\mathrm{i}}{ }_{\mathrm{C}-\mathrm{CV}}-\mathrm{F}^{\mathrm{i}}{ }_{\mathrm{C}-\mathrm{AV}}\right)}{\mathrm{F}^{\mathrm{i}}{ }_{\mathrm{C}-\mathrm{CV}}}
$$

where $F_{C-C V}^{i}$ and $F_{C-A V}^{i}$ are frequencies of codons $C-C V$ and $C-A V$, and $N$ is the number of variations (mutations) in the analyzed dataset. Under the assumption that more frequent codons are translated more efficiently [40,48,50-54], positive $S_{H}$ values imply that translation of mutated codons is less efficient.

A Monte Carlo procedure was used to estimate the significance of the differences in $S_{H}$. Random synonymous mutations were simulated taking into account the frequencies of substitutions for each nucleotide and the context of the mutating sites in the case of CpG dinucleotides (distinguishing mutations in the first and second CpG positions). A distribution of $\mathrm{S}_{\mathrm{H}} \_\mathrm{r}$ values was calculated for 10,000 groups of random mutations. Each of the resulting random mutation spectra contained the same number of mutations as the observed AV set with the same distribution of mutation types (Table 2) over randomly chosen synonymous sites for each gene. The distribution of $\mathrm{S}_{\mathrm{H} \_} \mathrm{r}$ was used to calculate the probability $\mathrm{P}\left(\mathrm{S}_{\mathrm{H}} \leq \mathrm{S}_{\mathrm{H} \_} \mathrm{r}\right)$. This probability is equal to the fraction of random spectra in which $S_{H_{-}} r$ is the same as or greater than the $\mathrm{S}_{\mathrm{H}}$. Similarly, $\mathrm{P}\left(\mathrm{S}_{\mathrm{H}} \leq \mathrm{S}_{\mathrm{H} \_} \mathrm{r}\right)$ values for the sets of reconstructed synonymous mutations, common SNPs and de novo mutations were calculated.

The same Monte Carlo approach was applied to analyze the potential impact of AVs on mRNA free energy and on splicing enhancers. The mRNA sequences of 19 genes (Table 1) were computationally "folded" and the predicted minimum free energy of the secondary structure was calculated using an algorithm that employs nearest neighbor parameters to evaluate free energy $[55,56]$. Similar to codon usage, the change in free energy divided by the value of the free energy of common allele variants was used as $\mathrm{S}_{\mathrm{H}}=\Sigma\left(\mathrm{FE}_{\mathrm{C}_{-} \mathrm{CM}}-\mathrm{FE}_{\mathrm{C}_{-} \mathrm{AV}}\right) / \mathrm{FE}_{\mathrm{C}_{-} \mathrm{CM}}\left(\mathrm{FE}_{\mathrm{C}_{-} \mathrm{CM}}\right.$ is the minimum free energy of a common variant, $\mathrm{FE}_{\mathrm{C}_{-} \mathrm{AV}}$ is the free energy of AV). Lists of splicing enhancers/silencers were from $[57,58]$. The $S_{H}$ was defined as the number of changes of splicing enhancers/silencers (gains or losses of splicing enhancers/silencers as the result of variations).

\section{No effect of AVs on splicing enhancers/silencers, mRNA} secondary structure and exonic transcription factor binding Selection at synonymous sites in mammals is a longstanding problem. It has been shown that some synonymous sites in mammalian genes are subject to selective pressure, possibly because of constraints acting on regulatory elements (such as splicing enhancers) located within exons [51,58-64]. Exonic splicing enhancers (ESEs) and silencers (ESSs) appear to be present in most, if not all, mammalian exons [59-61]. In the present analysis, no connection between ESEs/SSEs and the AVs was detected: $\mathrm{P}\left(\mathrm{S}_{\mathrm{H}} \leq \mathrm{S}_{\mathrm{H} \_} \mathrm{r}\right)=0.213$ for the ESE/SSE set [58] and $\mathrm{P}\left(\mathrm{S}_{\mathrm{H}} \leq \mathrm{S}_{\mathrm{H} \_} \mathrm{r}\right)=0.713$ for the RESCUE-ESE set [57].

It also has been proposed that purifying selection on synonymous sites had to do with changes in mRNA stability [40,51,65-67]. Thus, we compared the predicted mRNA structures for the polarized rare synonymous variations in the AV set and the common variants. No significant stabilization or destabilization of the mRNA structure in the AVs was detected $\left[\mathrm{P}\left(\mathrm{S}_{\mathrm{H}} \leq \mathrm{S}_{\mathrm{H} \_} \mathrm{r}\right)=0.189\right]$. Thus, stability of mRNA structure or ESEs/ESSs does not seem to be significantly affected by the AVs.

Recently, it has been shown that exonic transcription factor binding directs codon choice through the dual function of many codons that additionally contribute to transcription factor binding site [68]. The dual function codons are concentrated primarily in the $5^{\prime}$-terminal regions of protein-coding sequences. Therefore we addressed the possibility that AVs affected transcription factor binding. The distribution of AVs across the coding regions of the 19 genes was nearly uniform (Additional file 2) which is inconsistent with a significant effect of AVs on transcription factor binding sites.

\section{The AVs result in less frequent codons}

In some metazoan species (e.g. Drosophila and nematode), synonymous codon usage appears to evolve under selective pressure to optimize the efficiency of translation of highly expressed genes (the translational selection model) [69]. The impact of translational selection on synonymous codon usage in mammals is uncertain, and codon usage is often considered to be effectively neutral $[47,51,69,70]$. However, recent analyses indicate that selection on translation efficiency in mammals could be measurable as suggested by the detected correlations between codon adaptation index and several variables related to the functional importance of proteins including gene essentiality, expression level and evolutionary rate [52,53]. Most of the AVs cause replacement of more frequent codons by less frequent codons (68 out of $87 \mathrm{AVs}$ ). However, this trend might result from mutational biases [47], especially given that many variations occurred in $\mathrm{CpG}$ dinucleotides (Table 2). We used Monte Carlo stimulations to estimate the significance of changes in codon usage, taking into account DNA context properties of mutations (see above). The distribution of shifts in codon usage for random mutations $\left(S_{\mathrm{H}} \mathrm{r}\right)$ is shown in Figure 1 . The $\mathrm{S}_{\mathrm{H}}$ value for the AVs is 22.7, and only a small fraction of $S_{H \_} r(0.007)$ 


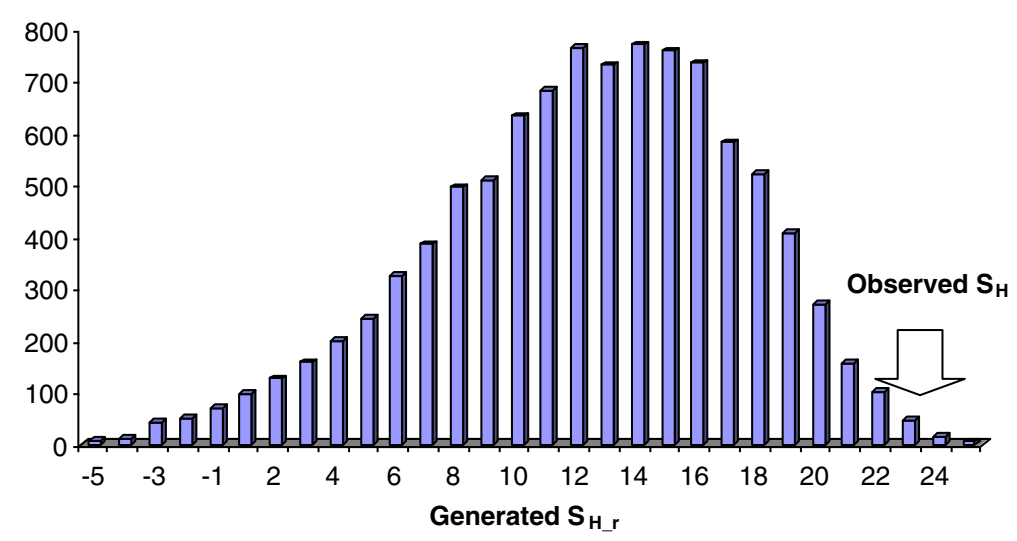

Figure 1 Distribution of the mean codon usage shift $\left(\mathrm{S}_{\mathrm{H}} \mathbf{r}\right)$ for $\mathbf{1 0 , 0 0 0}$ groups of generated mutations. Codon usage shift ( $\left.\mathrm{S}_{\mathrm{H}}\right)$ for observed synonymous mutations: 22.7, $\mathrm{P}\left(\mathrm{S}_{\mathrm{H}} \leq \mathrm{S}_{\mathrm{H}_{-}} \mathrm{r}\right)=0.007$. Monte Carlo stimulation was used to estimate the significance of changes in codon usage, taking into account DNA context properties of mutations (see text for details). Codon frequencies for the brain-specific genes were estimated by Semon and co-workers [47].

showed equal or greater values (Figure 1). Thus, the observed shift in codon usage associated with AVs is unlikely to be due to chance $\left[\mathrm{P}\left(\mathrm{S}_{\mathrm{H}} \leq \mathrm{S}_{\mathrm{H} \_} \mathrm{r}\right)=0.007\right]$. We complemented this analysis using codon frequencies in the set of 19 AV-containing genes (Table 1) and the microarray-based set of brain-specific genes [48], with nearly identical results $\left[\mathrm{P}\left(\mathrm{S}_{\mathrm{H}} \leq \mathrm{S}_{\mathrm{H} \_} \mathrm{r}\right)=0.006\right.$ for the 19 gene set and $\mathrm{P}\left(\mathrm{S}_{\mathrm{H}} \leq \mathrm{S}_{\mathrm{H} \_} \mathrm{r}\right)=0.005$ for the alternative brain-specific gene set].

A comparable codon usage shift was not observed for de novo mutations $\left[\mathrm{P}\left(\mathrm{S}_{\mathrm{H}} \leq \mathrm{S}_{\mathrm{H} \_} \mathrm{r}\right)=0.171\right]$. These de novo mutations are an important control because the vast majority of them are not related to ASD and rather reflect properties of spontaneous mutations in humans $[6,7,45]$. No significant codon usage shift was detected for the set of reconstructed synonymous mutations $\left[\mathrm{P}\left(\mathrm{S}_{\mathrm{H}} \leq \mathrm{S}_{\mathrm{H} \_} \mathrm{r}\right)=\right.$ 0.636] and the set of common SNPs $\left[\mathrm{P}\left(\mathrm{S}_{\mathrm{H}} \leq \mathrm{S}_{\mathrm{H} \_} \mathrm{r}\right)=\right.$ 0.291 ] either. Thus, the shift in codon usage toward rare codons is not a general property of spontaneous mutations in the analyzed set of 19 ASD-associated genes (Table 1).

One obvious limitation of this analysis is the small numbers of variations/mutations (Table 2). To assess the impact of the dataset size, we applied the jackknife procedure: $\mathrm{X}$ mutations were randomly removed from the AV set and $\mathrm{P}\left(\mathrm{S}_{\mathrm{H}} \leq \mathrm{S}_{\mathrm{H}} \mathrm{r}\right)$ was estimated for this smaller subset of AVs. This procedure was repeated 1000 times for each $X(X=10,20,26,30,40 ; X=26$ corresponds to the smallest set of common synonymous SNPs, Table 2). The results of the jackknife analysis are shown in the Table 3. For $X=10,20,26,30$, the vast majority of $\mathrm{P}\left(\mathrm{S}_{\mathrm{H}} \leq \mathrm{S}_{\mathrm{H} \_} \mathrm{r}\right.$ ) values were smaller than 0.05 (significant codon usage shift); only for $X=40$, the results were notably less reliable even though for all $\mathrm{X}$ values, the mean $\mathrm{P}$ value was below 0.05 (Table 3 ). Thus, the relatively small size of the AV dataset and other datasets analyzed here does not preclude reliable conclusions on the significance of the codon usage shift. It should be noted that careful selection and validation of the genes associated with ASD and the AVs themselves provided by the authors of the initial datasets [41,42] compensated for the small size of the AV set.

\section{Implications of the hypothesis}

We show here that rare synonymous variations in 19 genes associated with ASD cause a significant shift of codon usage towards rare codons and therefore might reduce the efficiency of translation. An example of such rare synonymous variation was found in the MDR1 gene; this rare synonymous variation results in the protein product with altered drug and inhibitor interactions $[71,72]$. We hypothesize that the impact of rare codons on the translation of genes involved in neuron development, even if slight in magnitude, could contribute to the pathogenesis of ASD in the presence of an aggressive chemical background (Figure 2). In several single-gene disorders with a high prevalence of autism, the mutated gene products are negative regulators of protein synthesis [38]. For example, the product of the FMR1 gene, the fragile $\mathrm{X}$ mental retardation protein (FMRP), binds to specific mRNAs and represses their translation. The FMRP protein is estimated to interact with more than 400 mRNAs [73]. These findings are consistent with the observation that de novo disruptions of genes regulated by the FRMP translation repressor are prevalent in children with ASD [7]. Kelleher and Bear proposed that the "autistic neuron" is a result of perturbed translation and the defects in translation repression might represent one possible etiological factor of autism [7,38,74,75].

Rare codons can substantially alter the dosage of proteins through different mechanisms, in particular ribosome pausing and "drop off" from the mRNA, often 
Table 3 Jackknife analysis of the rare synonymous variations in genes associated with ASD (the AV set)

\begin{tabular}{cccc}
\hline Number of removed $\mathbf{A V} \mathbf{s}$ & Mean $\mathbf{P}\left(\mathbf{S}_{\mathbf{H}} \leq \mathbf{S}_{\mathbf{H} \_} \mathbf{r}\right)$ & Standard error & Fraction of cases with $\mathbf{P}\left(\mathbf{S}_{\mathbf{H}} \leq \mathbf{S} \mathbf{S}_{\mathbf{H} \_} \mathbf{r}\right) \leq \mathbf{0 . 0 5}$ \\
\hline 10 & 0.0031 & 0.0004 & 0.988 \\
20 & 0.0233 & 0.0007 & 0.939 \\
26 (corresponds to the common SNP dataset) & 0.0279 & 0.002 & 0.886 \\
30 & 0.0323 & 0.002 & 0.839 \\
40 & 0.0451 & 0.003 & 0.718 \\
\hline
\end{tabular}

Codon frequencies for the brain-specific genes were estimated by Semon and co-workers [47].

followed by decay of the mRNA and the partly completed protein product $[76,77]$. Dosage imbalance of proteins associated with neuron development is known to be important in many psychiatric disorders [78-80]. Currently, there seem to be no direct indications that dosage imbalance of neuron-specific proteins is involved in ASD. However, indirect evidence includes multiple reports on apparent involvement of molecular chaperones, in particular the heat shock protein $70 \mathrm{kDa}$ family (Hsp70) that facilitates cotranslational folding of large, slowly translated and aggregation-prone proteins [81-83]. Prolonged episodes of fever are known to cause induction of heat shock protein response along with a two-three fold increased risk of infantile ASD [84-86]. Neurotoxicity also leads to heat shock protein response including Hsp70 induction [87]. Elevation of the Hsp70 level in rat brain homogenates has been detected in response to the treatment with the neurotoxin propionic acid [88] that has been used to develop a rat model of ASD [89]. Micromolar concentrations of another neurotoxin, sodium azide, in human cell cultures induce a cytoplasm to nucleus translocation and overall upregulation of Hsp70 [90]. In utero exposure to valproic acid, a mood stabilizer, is associated with increased risk of autism in humans and autistic-like behaviors in rodent models $[91,92]$. Valproic acid treatment induces functional Hsp70 in cortical rat neuron cell cultures [93]. Conceivably, the induction of Hsp70 by factors associated with ASD might contribute to protein imbalance that is likely to play a role in the etiology of this disease.

Under the present hypothesis (Figure 2), the ASD surge is, at least partially, caused by the interplay between human genetic background, in particular that associated with perturbed translation, and increased exposure to an unidentified neurotoxin(s). Many growing environmental hazards could be at fault [34-37]. It seems likely, however, that the synergistic action of such hazards with mutations

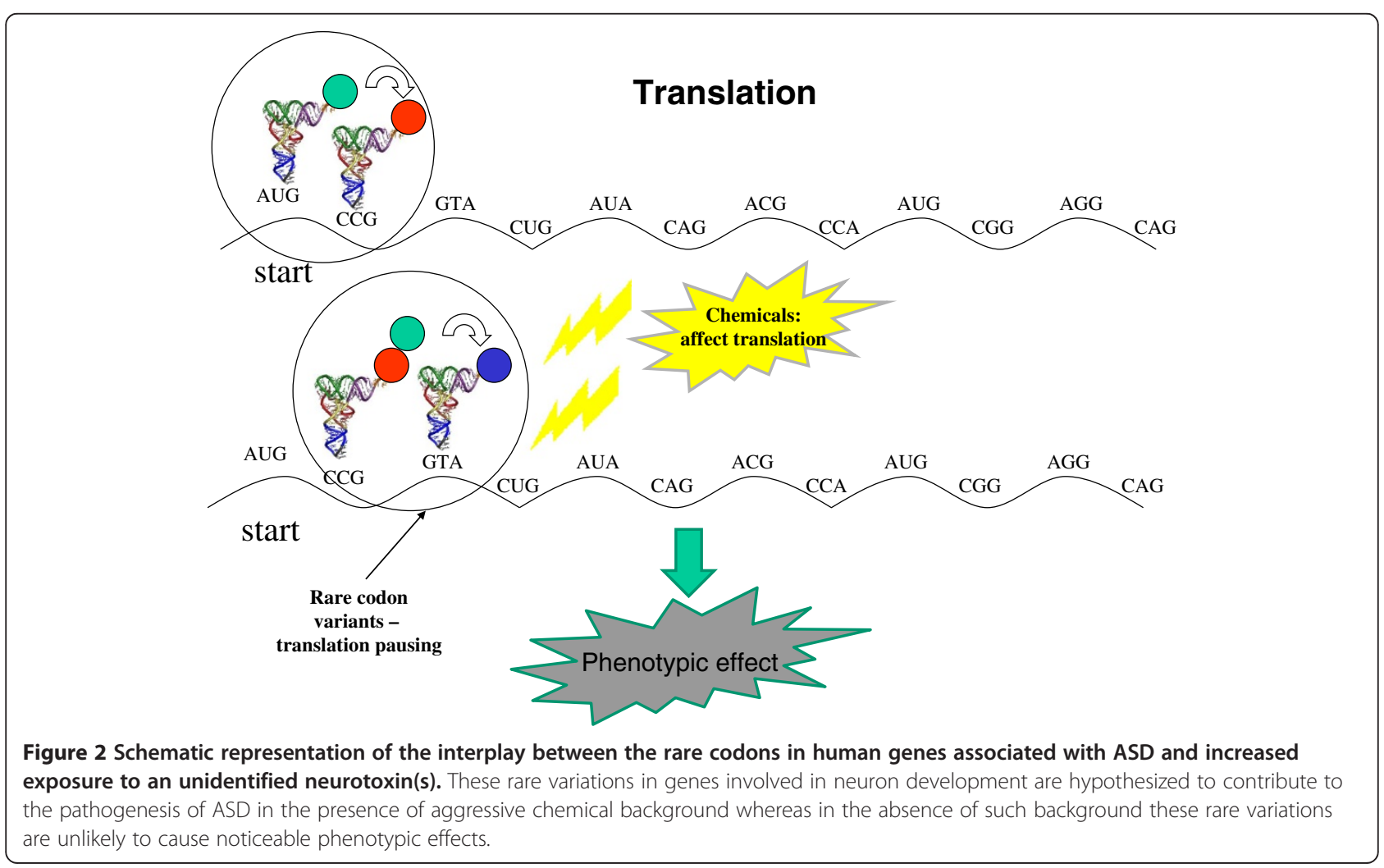


that in themselves have limited or no deleterious effects but are potentiated by the environmental factors is a general principle that underlies the alarming increase in the ASD prevalence.

Some aspects of this hypothesis can be tested via further epidemiological studies, direct biochemical experiments aimed at the elucidation of the effects of synonymous substitutions, in particular in relation to stress and chaperone activity, and the in vivo effects of these mutations in animal models.

\section{Reviewers' comments}

Reviewer \#1: Andrey Rzhetsky, University of Chicago, United States of America

Every hypothesis should have an opportunity to be presented for future testing with data; I would support an opportunity to voice this particular suggestion. I enjoyed reading the introduction to the paper-it covers well the diversity of proposed hypothetical genetic and environmental etiologies for ASD.

However, the particular hypothesis proposed by the authors does not really explain the mechanism of disease. In its essence, this is a limited genetic explanation (limited to a subset of protein-coding nucleotide substitutions). It does not account for increase of the apparent ASD rate (except the factors reviewed in the introduction, but the hypothesis is disconnected from these factors). Essentially, the authors suggest that mildly deleterious synonymous substitutions in protein-coding genes related to neurodevelopmental functions change the efficiency of translation process. The idea is that closer-to-theoptimum (corresponding to the maximum-concentration tRNA isoacceptor) codons are replaced with less optimal ones, slowing translation. It is unclear what the authors think about more serious defects in the same genes (nonsynonymous, nonsense, missense, etc.)? Would they result in the same phenotype or be lethal or neutral?

Authors' response: The presented hypothesis is not actually disconnected from the factors that are implicated in the increased incidence of ASD. Indeed, the hypothesis focuses on the interplay between genetic changes that could moderately affect translation in synergy with neurotoxins that elicit heat shock protein response and also affect translation, in particular through the change in the abundance of the nascent chain chaperone, heat shock $70 \mathrm{kDa}$ protein 8 (HSPA8) which is required for the translation of many large or aggregation-prone proteins. We speculate that these two factors synergistically lead to protein dosage imbalance that contributes to the autistic phenotype. A recent systematic review of potential associations between environmental toxins and ASD demonstrated that the etiology of ASD is likely to involve, at least in a subset of children, complex interactions between genetic factors and environmental toxicants that might act synergistically or in parallel during critical periods of neurodevelopment [94]. The role of nonsense and missense mutations in these interactions is indeed far from being clear. There are indications that some de novo non-synonymous substitutions could be associated with various intellectual disabilities but the functional impact of these mutations is not well understood [45]. In general, ASD is a complex, multifactorial disorder [95-98] which makes construction of straightforward explanatory models highly problematic. Currently, we are still at the stage of searching for factors that are significantly and substantially associated with ASD.

On a more technical level, I would draw attention to the statistical testing suggested in the manuscript. "Statistical significant shift from optimal" codon frequencies may well agree with a random drift: assuming that all codons are in near-optimum (which is not true, of course) the overwhelming majority of possible random synonymous substitutions will inevitably push the distribution of codons away from optimum. I think, this particular test does not really support or refute the hypothesis. Essentially, it says that random synonymous nucleotide changes are very unlikely to result in low-entropy optimal codon distribution.

Authors' response: The problem with models of random mutations does exist in many applications $[99,100]$. For example, a model proposed by McFarland and coworkers [100] accounts for three types of synonymous substitutions: transversions, CpG to TpG transitions, and all other transitions. We implemented a more complex statistical model of random mutations which takes into account the frequencies of substitutions for each nucleotide and the context of the mutating sites in the case of $\mathrm{CpG}$ dinucleotides (distinguishing mutations in the first and second $\mathrm{CpG}$ positions, see text for more detail). We believe that this model captures statistical properties of background mutation process in detail and is similar to the model developed for human germ-line mutations $[100,101]$. Although under this model, we showed the shift of the generated random mutations away from the optimum for AVs, the shift was substantially smaller than that observed with the actual AVs in the ASD patients (Figure 1). Notably, this was not the case for some other conditions. For example, for de novo mutations found in patients with schizophrenia, the opposite shift from less optimal to more optimal codons was observed (see more details in our response \#3 to Dr. Smalheiser below), and in this case, random mutations under the same model also exhibit such a shift. Thus, the outcome of the model of random mutations strongly depends on the frequencies and context of the analyzed variations/ mutations 


\section{Reviewer \#2: Neil R. Smalheiser, University of Illinois at Chicago, United States of America}

This article provides strong evidence that synonymous genetic variants associated with autism tend to produce less-favored codon usage, which provides further evidence in favor of the notion that impaired translation is a key risk factor, and possibly a core pathogenetic feature, of autism.

I recommend that the authors make the following clarifications:

1. Can you comment on Shank3, which has 27 synonymous variants? Is there any chance that this single case is skewing the results from the entire set? Is there anything in particular about Shank3 that makes it particularly susceptible to control via translational rate?

Authors' response: SHANK3 is indeed an outlier in terms of the number of AVs (Table 1), one possible explanation is that this gene has a long coding sequence (5244 nucleotides). In order to test for potential skew of the results by the excessive amount of rare variations in this gene, we performed an additional experiment. We randomly sampled S\% out of 27 AVs observed in SHANK3 without changing the rest of the AV set $(S=10 \%, 25 \%$, $33 \%, 50 \%)$. This sampling was repeated 100 times for each value of $\mathrm{S}$. In all 400 experiments, the $\mathrm{P}$ value was less than 0.01 , even for $\mathrm{S}=10 \%$ (3 AVs in SHANK3). This result indicates that the excess of mutations in SHANK3 does not significantly influence in any way conclusions of our study.

2. To extend the comment about Shank3, is there anything ELSE in terms of features of the autism gene set which would render them particularly susceptible to control via codon usage? These might be covariates that work together with codon usage and are worth knowing about, if they exist.

Authors' response: We certainly agree that this is the key issue. We looked for such correlates of codon usage but failed to detect anything obvious. Nevertheless, we speculate that heat shock protein response (e.g., HSPA8 upregulation) is involved as an amplifier of the codon usage effect for large, aggregation-prone proteins and membrane proteins that are translocated in a semi-folded state.

3. Can you contrast the autism data with some other diseases that do NOT show the same trend? Maybe a brain disease whose incidence has not been increasing recently, and maybe a non-brain disease, etc. It would be very helpful to define neuropsychiatric disorders according to those which do, and which do not, show a relation of synonymous variants to less favored codons.

Authors' response: This is an important question that certainly has to be addressed in the future. So far we analyzed limited sets of de novo mutations and synonymous variations associated with schizophrenia extracted from three previous studies [102-104]. For de novo synonymous mutations, we did not find any significant codon usage shift $\left[\mathrm{P}\left(\mathrm{S}_{\mathrm{H}} \leq \mathrm{S}_{\mathrm{H} \_} \mathrm{r}\right)=0.868\right.$ for 27 mutations in 27 genes, $\left.S_{H}=-6.12\right]$. For the rare synonymous variations we did not find any trends either $\left[\mathrm{P}\left(\mathrm{S}_{\mathrm{H}} \leq \mathrm{S}_{\mathrm{H}_{-}} \mathrm{r}\right)=\right.$ 0.804 for 5 mutations in 2 genes, $S_{H}=0.98$ ]. Thus, unlike the case of ASD described in the present paper, we did not observe any significant shift towards more rare codons although these preliminarily results should be interpreted with caution given the small sample sizes.

4. The title talks about translation "in neurons", but is that warranted? What is the evidence that neurons are the critical compartment? All neurons? But not glial cells? Neuronal cell body vs. local translation in dendrites or at synapses? Most of the autism gene set are not brain specific, either, so it is conceivable that changes in other organs are contributory (e.g., liver, if it is detoxifying environmental toxins?).

Authors' response: The problem of cell/tissue specificity of gene sets is indeed important. We used published gene sets from two studies [41,42] assuming that these were well curated and have biological implications in ASD. One of the theories of autism development involves excessive neuron number and atypical neural "connectivity" [105-107]. Some microglia activation was observed in autistic brains together with aberrantly close microglia-neuron associations whereas the organization of microglia itself appeared normal [108]. Although aberrant synaptic pruning was implied in pathogenesis of autism, it might be too early to address finer defects inside neurons [109]. However, recent studies have shown clear benefits of glutamate blockers in a number of animal models of ASD and fragile X syndrome [110-112]. Antagonists of metabotropic glutamate receptor subtype 5 (mGluR5) currently are in clinical trials for fragile X syndrome $(\sim 30 \%$ of patients meet the diagnostic criteria for autism) [113], a major genetic cause of intellectual disabilities. This signaling pathway is related to the regulation of synapses and neuronal circuits, and therefore neurons are the likely primary target of translational defects in autism. However, liver function is directly connected to brain health and function and recently a case study has been published in which liver transplant reversed autistic symptoms and mental delays in a child [114]. Thus, we cannot exclude a role of protein expression in liver in the etiology of ASD although there are no detoxification enzymes on our list of genes with ASD-related mutations (Table 1).

5. The least satisfying part of the paper is the discussion/speculation how translational defects might interact with environmental toxins. If the relation between synonymous changes and codon usage is truly specific to autism, that might explain why the incidence of 
autism is selectively increasing (when combined with environmental factors). It would help to have a better framework of exactly how the two effects might interact or synergize, than you have currently.

Authors' response: We believe that we did our best to outline potential biological links between the shift in codon usage and putative environmental factor(s), without overstating the case which is far from being clear at this stage. We suggest that heat shock response in a high neurotoxin load environment would synergize with the codon usage effect. One example of an increasingly used toxin is sodium azide that, in addition to its wellknown effects as an inhibitor of cytochrome c oxidase $[90,115,116]$ and a stimulant of soluble guanylate cyclase [117], has been shown to inhibit translation initiation at millimolar concentrations [118]. Furthermore, micromolar exposures in cell cultures to sodium azide have been reported to cause cytoplasm to nucleus translocation of inducible forms of Hsp70 and of Hsp40, and overall upregulation of heat shock protein response [90], and accordingly, would affect translation through nascent chain chaperone function of inducible forms of Hsp70 and other heat shock proteins $[81,82]$. Given the apparent importance of defects in translation and in particular in translation repression $[7,38]$, increased exposure to sodium azide might contribute to the observed increased prevalence of ASD synergistically with rare synonymous variations and mutations impairing translation, even without an increase in the rate of such variations/mutations. Sodium azide is widely used as inhibitor of bacterial growth, pesticide, and most important, propellant for car air bags with an uncertain fate in the environment [119]. All these indications notwithstanding, it should be noted that sodium azide is discussed as a potential culprit in the ASD surge as an example. Many other growing environmental hazards could be at fault alternatively or additionally.

6. Is this paper relevant to your arguments? Petrovski S, Wang Q, Heinzen EL, Allen AS, Goldstein DB. Genic intolerance to functional variation and the interpretation of personal genomes. PLoS Genet. 2013; 9(8): e1003709.

Authors' response: This paper is indeed relevant because it emphasizes that de novo synonymous mutations are likely to be a good control set; we now cite this reference in the discussion of this issue.

7. In your final paragraph, you state that it is "clear" how to test your hypothesis. I think it would be better to spell out some specific tests anyway, especially focusing on the best and most critical tests.

Authors' response: One of the venues for future research could be development of animal models to directly test our hypothesis. In our opinion, valproic acid and sodium azide are appropriate neurotoxins to study autistic behavior in mice [91]. One could analyze phenotype of already developed SHANK3 mutant mice in the presence of neurotoxins [120]. Another possibility is to construct mutated SHANK3 mice with changes in codon usage, e.g. using some of the 27AVs from our list.

\section{Reviewer \#3: Shamil R. Sunyaev, Brigham \& Women's Hospital and Harvard Medical School, United States of America}

This manuscript addresses potential molecular mechanisms underlying genetic susceptibility to autism. The authors suggest that synonymous mutations impacting translation efficiency may play a significant role. This is a highly important area of research, and the authors state an interesting hypothesis. However, I am not convinced by the provided evidence.

1) There are no data on the importance of de novo synonymous mutations in autism. The only convincing enrichment has been observed for nonsense and frameshift mutations, the mutations of very large effects. There is no signal for any other class of mutations. Incorporation of an unpreferred codon is unlikely to be functionally equivalent to a complete loss of function. Next, the enrichment in nonsense mutations is probably limited to cases where autism is associated with intellectual disability and is not observed in patients with high non-verbal IQ. It is, therefore, likely that cases of monogenic intellectual disability are, at least partly, responsible for the observed enrichment. As far as I know, there is no evidence that synonymous mutations cause monogenic forms of intellectual disability.

Authors' response: We are not aware of synonymous mutations that cause monogenic forms of intellectual disability. In general, monogenetic disorders (e.g., fragile $\mathrm{X}$ syndrome, Rett syndrome, and neurofibromatosis) that have phenotypic overlap with autism imply impaired synaptic development and function but the fraction of monogenic forms of intellectual disability among all forms of this condition is not well defined [121,122]. Some studies even question the possibility of any substantial impact of monogenic forms of ASD [97]. ASD is known to be a complex multifactorial disease [95-98,123] although several rare single-gene disorders with a high prevalence of ASD are known $[38,113]$. We speculate that the impact of synonymous variations/mutations is small but sufficient to produce phenotypic effects in synergy with the increasing neurotoxin load. This hypothesis is effectively orthogonal to the existence of monogenic conditions caused by synonymous mutations.

2) It is clear that de novo mutations would be expected to be biased towards unpreferred codons because fixation biases due to selection or biased gene conversion reduce frequencies of unpreferred codons. The authors observed a bias in favor of unpreferred codons in synonymous mutations involved in autism and in a corresponding trend in 
control mutations. The proper statistical test would be to compare sets of mutations in patients and mutations in unaffected controls (better in the same genes) matched for paternal age. Comparisons with a model or segregating human SNPs are not convincing.

Authors' response: We are not sure that de novo synonymous mutations are"... biased towards unpreferred codons because fixation biases due to selection or biased gene conversion reduce frequencies of unpreferred codons". We did not observe any significant trends in our study. In fact, the bias "towards unpreferred codons" is not obvious feature of de novo mutations, for example, a recent analysis of large collections of de novo mutations in diploid yeast cells did not reveal any obvious signs of selection at the level of coding sequences as suggested by tests of selection that are based on ratios of nonsynonymous/synonymous substitutions and radical/conservative non-synonymous mutations [124]. In this work we observed a trend toward unpreferred codons for rare genomic variations (the analyzed AV set) as defined by two previous studies [41,42] and compared the trend in this set with those in several control sets including de novo mutations in ASD patients and common SNPs (Table 2). We believe that de novo mutations in ASD patients (Table 2) comprise the control set closest to the set of rare synonymous variations in genes associated with ASD (the studied AV set). However, we decided to follow the suggestion of the reviewer and analyzed available sets of de novo synonymous mutations in unaffected individuals from two previous studies [6,7]. This set contains 103 mutations (31 mutations in CpG dinucleotides). In this set of de novo synonymous mutations, we did not observe any significant codon usage shift $\left[\mathrm{P}\left(\mathrm{S}_{\mathrm{H}} \leq \mathrm{S}_{\mathrm{H} \_} \mathrm{r}\right)=\right.$ 0.485]. The current data on de novo mutations do not allow comparisons of "sets of mutations in patients and mutations in unaffected controls (better in the same genes) matched for paternal age", however, we find it unlikely that even much larger sets of de novo mutations (controlled for genes and parental age) could change the conclusions of the present work. Once again, the only trend that we observed is the significant codon usage shift for rare synonymous variations in genes associated with ASD (the AV set, Table 1). However, it is possible to use another control set for the AV set, namely rare synonymous variations that have been detected in the AV set of genes (Table 1) from unaffected siblings of ASD patients (controls according to Kelleher and co-workers [42]). Unfortunately, this set contains only 51 rare synonymous variations that is why we have not included it in the original version of this paper. Nevertheless, analysis of these rare variations revealed a trend of codon usage shift that is fully consistent with our hypothesis: the $\mathrm{S}_{\mathrm{H}}$ value for the rare synonymous variations in unaffected siblings was extremely small $\left(S_{H}=1.4\right)$, in a sharp contrast with the AV set $\left(S_{H}=22.7\right)$. Moreover, the observed value $\mathrm{S}_{\mathrm{H}}=1.4$ is significantly smaller compared to the corresponding set of random synonymous mutations [mean $\left.\mathrm{S}_{\mathrm{H} \_\mathrm{r}}=8.2, \mathrm{P}\left(\mathrm{S}_{\mathrm{H}} \geq \mathrm{S}_{\mathrm{H} \_\mathrm{r}} \mathrm{r}\right)=0.045\right]$. These observations suggest that rare synonymous variations in unaffected siblings of ASD patients have negligible effect on translation of the respective mRNAs although these findings should be interpreted with caution given the small sample size.

\section{Additional files}

Additional file 1: List of rare synonymous variations in genes associated with ASD (the AV set) used in this study.

Additional file 2: Distribution of rare synonymous variations in genes associated with ASD (the AV set) across protein-coding sequences of the 19 genes.

\section{Abbreviations}

ASD: Autistic spectrum disorders; AVs: Rare synonymous variations in genes associated with ASD; SNP: Single nucleotide polymorphism; ESEs: Exonic splicing enhancers; ESSs: Exonic splicing silencers; Hsp70: the heat shock protein $70 \mathrm{kDa}$ family.

\section{Competing interests}

The authors declare that they have no competing interests.

\section{Authors' contributions}

EP, EVK and IBR incepted the study. EP and IBR implemented the tests and performed data analysis. EP, EVK and IBR wrote the manuscript which was read, edited, and approved by all authors.

\section{Acknowledgments}

This work was supported by the by the Intramural Research Program of the National Eye Institute and the Intramural Research Program of the National Library of Medicine at the National Institutes of Health (US Department Health and Human Services).

\section{Author details}

'Laboratory of Retinal Cell \& Molecular Biology, National Eye Institute, National Institutes of Health, Bethesda, MD, USA. ${ }^{2}$ National Center for Biotechnology Information, National Library of Medicine, National Institutes of Health, Bethesda, MD, USA.

Received: 1 April 2014 Accepted: 1 July 2014

Published: 10 July 2014

\section{References}

1. Wingate M, Kirby RS, Pettygrove S, Cunniff C, Schulz E, Ghosh T, Robinson C, Lee LC, Landa R, Constantino J, Fitzgerald R, Zahorodny W, Daniels J, Nicholas J, Charles J, McMahon W, Bilder D, Durkin M, Baio J, Christensen D, Braun KV, Clayton H, Goodman A, Doernberg N, Yeargin-Allsopp M, Lott E, Mancilla KC, Hudson A, Kast K, Jolly K, et al: Prevalence of autism spectrum disorder among children aged 8 years - autism and developmental disabilities monitoring network, 11 sites, United States, 2010. MMWR Surveill Summ 2014, 63(2):1-21.

2. Wingate M, Mulvihill B, Kirby RS, Pettygrove S, Cunniff C, Meaney F, Schulz E, Miller L, Robinson C, Quintana G, Kaiser MY, Lee LC, Landa R, Newschaffer C, Constantino J, Fitzgerald R, Zahorodny W, Daniels J, Giarelli E, Pinto-Martin J, Levy SE, Nicholas J, Charles J, Zimmerman J, Maenner MJ, Durkin M, Rice C, Baio J, Van Naarden Braun K, Phillips K, et al: Prevalence of autism spectrum disorders - autism and developmental disabilities monitoring network, 14 sites, United States, 2008. MMWR Surveill Summ 2012, 61(3):1-19.

3. Grandjean P, Landrigan PJ: Neurobehavioural effects of developmental toxicity. Lancet Neurol 2014, 13(3):330-338.

4. Neale BM, Kou Y, Liu L, Ma'ayan A, Samocha KE, Sabo A, Lin CF, Stevens C, Wang LS, Makarov V, Polak P, Yoon S, Maguire J, Crawford EL, Campbell NG, 
Geller ET, Valladares O, Schafer C, Liu H, Zhao T, Cai G, Lihm J, Dannenfelser R, Jabado O, Peralta Z, Nagaswamy U, Muzny D, Reid JG, Newsham I, Wu Y, et al: Patterns and rates of exonic de novo mutations in autism spectrum disorders. Nature 2012, 485(7397):242-245.

5. O'Roak BJ, Deriziotis P, Lee C, Vives L, Schwartz JJ, Girirajan S, Karakoc E, Mackenzie AP, Ng SB, Baker C, Rieder MJ, Nickerson DA, Bernier R, Fisher SE, Shendure J, Eichler EE: Exome sequencing in sporadic autism spectrum disorders identifies severe de novo mutations. Nat Genet 2012. 43(6):585-589.

6. Sanders SJ, Murtha MT, Gupta AR, Murdoch JD, Raubeson MJ, Willsey AJ, Ercan-Sencicek AG, DiLullo NM, Parikshak NN, Stein JL, Walker MF, Ober GT, Teran NA, Song Y, El-Fishawy P, Murtha RC, Choi M, Overton JD, Bjornson RD, Carriero NJ, Meyer KA, Bilguvar K, Mane SM, Sestan N, Lifton RP, Gunel M, Roeder K, Geschwind DH, Devlin B, State MW: De novo mutations revealed by whole-exome sequencing are strongly associated with autism. Nature 2012, 485(7397):237-241.

7. Iossifov I, Ronemus M, Levy D, Wang Z, Hakker I, Rosenbaum J, Yamrom B, Lee YH, Narzisi G, Leotta A, Kendall J, Grabowska E, Ma B, Marks S, Rodgers L, Stepansky A, Troge J, Andrews P, Bekritsky M, Pradhan K, Ghiban E, Kramer M, Parla J, Demeter R, Fulton LL, Fulton RS, Magrini VJ, Ye K, Darnell $J C$, Darnell RB, et al: De novo gene disruptions in children on the autistic spectrum. Neuron 2012, 74(2):285-299.

8. Drake JW, Charlesworth B, Charlesworth D, Crow JF: Rates of spontaneous mutation. Genetics 1998, 148(4):1667-1686.

9. Kondrashov AS: Direct estimates of human per nucleotide mutation rates at 20 loci causing mendelian diseases. Hum Mutat 2003, 21(1):12-27.

10. Stenson PD, Mort M, Ball EV, Shaw K, Phillips AD, Cooper DN: The human gene mutation database: building a comprehensive mutation repository for clinical and molecular genetics, diagnostic testing and personalized genomic medicine. Hum Genet 2014, 133(1):1-9.

11. Ramos-Arroyo MA, Moreno S, Valiente A: Incidence and mutation rates of Huntington's disease in Spain: experience of 9 years of direct genetic testing. J Neurol Neurosurg Psychiatry 2005, 76(3):337-342.

12. Pringsheim T, Wiltshire K, Day L, Dykeman J, Steeves T, Jette N: The incidence and prevalence of Huntington's disease: a systematic review and meta-analysis. Mov Disord 2012, 27(9):1083-1091.

13. Kirkbride JB, Errazuriz A, Croudace TJ, Morgan C, Jackson D, Boydell J, Murray RM, Jones PB: Incidence of schizophrenia and other psychoses in England, 1950-2009: a systematic review and meta-analyses. PLoS One 2011, 7(3):e31660.

14. Stonebraker JS, Bolton-Maggs PH, Soucie JM, Walker I, Brooker M: A study of variations in the reported haemophilia a prevalence around the world. Haemophilia 2010, 16(1):20-32.

15. Scotet V, Dugueperoux I, Saliou P, Rault G, Roussey M, Audrezet MP, Ferec C: Evidence for decline in the incidence of cystic fibrosis: a 35-year observational study in Brittany, France. Orphanet J Rare Dis 2012, 7:14.

16. Yau V, Lynch F, Madden J, Owen-Smith A, Coleman K, Bent S, Massolo M, Pearson K, Crawford P, Freiman H, Pomichowski M: PS1-13: variation in the incidence and prevalence of autism from multiple health systems: findings from the mental health research network autism registry study. Clin Med Res 2013, 11(3):166.

17. Bishop DV, Whitehouse AJ, Watt HJ, Line EA: Autism and diagnostic substitution: evidence from a study of adults with a history of developmental language disorder. Dev Med Child Neurol 2008, 50(5):341-345.

18. Hertz-Picciotto I, Delwiche L: The rise in autism and the role of age at diagnosis. Epidemiology 2009, 20(1):84-90

19. King $M$, Bearman P: Diagnostic change and the increased prevalence of autism. Int J Epidemiol 2009, 38(5):1224-1234.

20. Grether JK, Rosen NJ, Smith KS, Croen LA: Investigation of shifts in autism reporting in the California department of developmental services. J Autism Dev Disord 2009, 39(10):1412-1419.

21. Deth R, Muratore C, Benzecry J, Power-Charnitsky VA, Waly M: How environmental and genetic factors combine to cause autism: a redox/ methylation hypothesis. Neurotoxicology 2008, 29(1):190-201.

22. Herbert MR: Contributions of the environment and environmentally vulnerable physiology to autism spectrum disorders. Curr Opin Neurol 2010, 23(2):103-110.

23. Garrecht M, Austin DW: The plausibility of a role for mercury in the etiology of autism: a cellular perspective. Toxicol Environ Chem 2011, 93(5-6):1251-1273.
24. Hallmayer J, Cleveland S, Torres A, Phillips J, Cohen B, Torigoe T, Miller J, Fedele A, Collins J, Smith K, Lotspeich L, Croen LA, Ozonoff S, Lajonchere C, Grether JK, Risch N: Genetic heritability and shared environmental factors among twin pairs with autism. Arch Gen Psychiatry 2011, 68(11):1095-1102.

25. Ritvo ER, Spence MA, Freeman BJ, Mason-Brothers A, Mo A, Marazita ML: Evidence for autosomal recessive inheritance in 46 families with multiple incidences of autism. Am J Psychiatry 1985, 142(2):187-192.

26. Smalley SL, Asarnow RF, Spence MA: Autism and genetics. A decade of research. Arch Gen Psychiatry 1988, 45(10):953-961.

27. Steffenburg S, Gillberg C, Hellgren L, Andersson L, Gillberg IC, Jakobsson G, Bohman M: A twin study of autism in Denmark, Finland, Iceland, Norway and Sweden. J Child Psychol Psychiatry 1989, 30(3):405-416.

28. Bailey A, Le Couteur A, Gottesman I, Bolton P, Simonoff E, Yuzda E, Rutter M: Autism as a strongly genetic disorder: evidence from a British twin study. Psychol Med 1995, 25(1):63-77.

29. Greenberg DA, Hodge SE, Sowinski J, Nicoll D: Excess of twins among affected sibling pairs with autism: implications for the etiology of autism. Am J Hum Genet 2001, 69(5):1062-1067.

30. Roberts EM, English PB, Grether JK, Windham GC, Somberg L, Wolff C: Maternal residence near agricultural pesticide applications and autism spectrum disorders among children in the California Central Valley. Environ Health Perspect 2007, 115(10):1482-1489.

31. Windham GC, Zhang L, Gunier R, Croen LA, Grether JK: Autism spectrum disorders in relation to distribution of hazardous air pollutants in the san francisco bay area. Environ Health Perspect 2006, 114(9):1438-1444.

32. Kalkbrenner AE, Daniels JL, Chen JC, Poole C, Emch M, Morrissey J: Perinatal exposure to hazardous air pollutants and autism spectrum disorders at age 8. Epidemiology 2010, 21(5):631-641.

33. Volk HE, Hertz-Picciotto I, Delwiche L, Lurmann F, McConnell R: Residential proximity to freeways and autism in the CHARGE study. Environ Health Perspect 2011, 119(6):873-877.

34. Croen LA, Grether JK, Yoshida CK, Odouli R, Hendrick V: Antidepressant use during pregnancy and childhood autism spectrum disorders. Arch Gen Psychiatry 2011, 68(11):1104-1112.

35. Landrigan PJ: What causes autism? Exploring the environmental contribution. Curr Opin Pediatr 2010, 22(2):219-225.

36. Rzhetsky A, Bagley SC, Wang K, Lyttle CS, Cook EH Jr, Altman RB, Gibbons RD: Environmental and state-level regulatory factors affect the incidence of autism and intellectual disability. PLoS Comput Biol 2014, 10(3):e1003518.

37. DeSoto MC: Ockham's razor and autism: the case for developmental neurotoxins contributing to a disease of neurodevelopment. Neurotoxicology 2009, 30(3):331-337.

38. Kelleher RJ 3rd, Bear MF: The autistic neuron: troubled translation? Cell 2008, 135(3):401-406.

39. Darnell JC, Van Driesche SJ, Zhang C, Hung KY, Mele A, Fraser CE, Stone EF, Chen C, Fak JJ, Chi SW, Licatalosi DD, Richter JD, Darnell RB: FMRP stalls ribosomal translocation on mRNAs linked to synaptic function and autism. Cell 2011, 146(2):247-261.

40. Sauna ZE, Kimchi-Sarfaty C: Understanding the contribution of synonymous mutations to human disease. Nat Rev Genet 2011, 12(10):683-691.

41. Basu SN, Kollu R, Banerjee-Basu S: AutDB: a gene reference resource for autism research. Nucleic Acids Res 2009, 37(Database issue):D832-D836.

42. Kelleher RJ 3rd, Geigenmuller U, Hovhannisyan H, Trautman E, Pinard R, Rathmell B, Carpenter R, Margulies D: High-throughput sequencing of mGluR signaling pathway genes reveals enrichment of rare variants in autism. PloS One 2012, 7(4):e35003.

43. Terekhanova NV, Bazykin GA, Neverov A, Kondrashov AS, Seplyarskiy VB: Prevalence of multinucleotide replacements in evolution of primates and drosophila. Mol Biol Evol 2013, 30(6):1315-1325.

44. Kimura M: The Neutral Theory of Molecular Evolution. Cambridge: Cambridge University Press; 1983.

45. Petrovski S, Wang Q, Heinzen EL, Allen AS, Goldstein DB: Genic intolerance to functional variation and the interpretation of personal genomes. PLOS Genet 2013, 9(8):e1003709.

46. Khromov-Borisov NN, Rogozin IB, Pegas Henriques JA, de Serres FJ: Similarity pattern analysis in mutational distributions. Mutat Res 1999, 430(1):55-74.

47. Semon M, Lobry JR, Duret L: No evidence for tissue-specific adaptation of synonymous codon usage in humans. Mol Biol Evol 2006, 23(3):523-529. 
48. Plotkin JB, Robins H, Levine AJ: Tissue-specific codon usage and the expression of human genes. Proc Natl Acad Sci U S A 2004, 101(34):12588-12591.

49. Warrington JA, Nair A, Mahadevappa M, Tsyganskaya M: Comparison of human adult and fetal expression and identification of 535 housekeeping/maintenance genes. Physiol Genomics 2000, 2(3):143-147.

50. Sharp PM, Li WH: The codon adaptation index-a measure of directional synonymous codon usage bias, and its potential applications. Nucleic Acids Res 1987, 15(3):1281-1295.

51. Chamary JV, Parmley JL, Hurst LD: Hearing silence: non-neutral evolution at synonymous sites in mammals. Nat Rev Genet 2006, 7(2):98-108.

52. Waldman YY, Tuller T, Shlomi T, Sharan R, Ruppin E: Translation efficiency in humans: tissue specificity, global optimization and differences between developmental stages. Nucleic Acids Res 2010, 38(9):2964-2974.

53. Waldman $Y Y$, Tuller T, Keinan A, Ruppin E: Selection for translation efficiency on synonymous polymorphisms in recent human evolution. Genome Biol Evol 2011, 3:749-761.

54. Plotkin JB, Kudla G: Synonymous but not the same: the causes and consequences of codon bias. Nat Rev Genet 2011, 12(1):32-42.

55. Zuker M: Mfold web server for nucleic acid folding and hybridization prediction. Nucleic Acids Res 2003, 31(13):3406-3415.

56. Ogurtsov AY, Shabalina SA, Kondrashov AS, Roytberg MA: Analysis of internal loops within the RNA secondary structure in almost quadratic time. Bioinformatics 2006, 22(11):1317-1324.

57. Fairbrother WG, Yeh RF, Sharp PA, Burge CB: Predictive identification of exonic splicing enhancers in human genes. Science 2002, 297(5583):1007-1013.

58. Ke $\mathrm{S}$, Zhang $\mathrm{XH}$, Chasin LA: Positive selection acting on splicing motifs reflects compensatory evolution. Genome Res 2008, 18(4):533-543.

59. Blencowe BJ: Exonic splicing enhancers: mechanism of action, diversity and role in human genetic diseases. Trends Biochem Sci 2000, 25(3):106-110.

60. Hurst LD, Pal C: Evidence for purifying selection acting on silent sites in BRCA1. Trends Genet 2001, 17(2):62-65.

61. Willie E, Majewski J: Evidence for codon bias selection at the pre-mRNA level in eukaryotes. Trends Genet 2004, 20(11):534-538.

62. Fairbrother WG, Holste D, Burge CB, Sharp PA: Single nucleotide polymorphism-based validation of exonic splicing enhancers. PLOS Biol 2004, 2(9):E268.

63. Dewey CN, Rogozin IB, Koonin EV: Compensatory relationship between splice sites and exonic splicing signals depending on the length of vertebrate introns. BMC Genomics 2006, 7:311.

64. Parmley $\mathrm{L}$, Chamary JV, Hurst LD: Evidence for purifying selection against synonymous mutations in mammalian exonic splicing enhancers. $\mathrm{Mol}$ Biol Evol 2006, 23(2):301-309.

65. Schaal TD, Maniatis T: Selection and characterization of pre-mRNA splicing enhancers: identification of novel SR protein-specific enhancer sequences. Mol Cell Biol 1999, 19(3):1705-1719.

66. Shabalina SA, Ogurtsov AY, Spiridonov NA: A periodic pattern of mRNA secondary structure created by the genetic code. Nucleic Acids Res 2006, 34(8):2428-2437

67. Resch AM, Carmel L, Marino-Ramirez L, Ogurtsov AY, Shabalina SA, Rogozin IB, Koonin EV: Widespread positive selection in synonymous sites of mammalian genes. Mol Biol Evol 2007, 24(8):1821-1831.

68. Stergachis AB, Haugen E, Shafer A, Fu W, Vernot B, Reynolds A, Raubitschek A, Ziegler S, LeProust EM, Akey JM, Stamatoyannopoulos JA: Exonic transcription factor binding directs codon choice and affects protein evolution. Science 2013, 342(6164):1367-1372.

69. Duret L: Evolution of synonymous codon usage in metazoans. Curr Opin Genet Dev 2002, 12(6):640-649.

70. Urrutia $A O$, Hurst LD: Codon usage bias covaries with expression breadth and the rate of synonymous evolution in humans, but this is not evidence for selection. Genetics 2001, 159(3):1191-1199.

71. Kimchi-Sarfaty C, Oh JM, Kim IW, Sauna ZE, Calcagno AM, Ambudkar SV, Gottesman MM: A "silent" polymorphism in the MDR1 gene changes substrate specificity. Science 2007, 315(5811):525-528.

72. Tsai CJ, Sauna ZE, Kimchi-Sarfaty C, Ambudkar SV, Gottesman MM, Nussinov $R$ : Synonymous mutations and ribosome stalling can lead to altered folding pathways and distinct minima. J Mol Biol 2008, 383(2):281-291.

73. Brown V, Jin P, Ceman S, Darnell JC, O'Donnell WT, Tenenbaum SA, Jin X, Feng Y, Wilkinson KD, Keene JD, Darnell RB, Warren ST: Microarray identification of FMRP-associated brain mRNAs and altered mRNA translational profiles in fragile $X$ syndrome. Cell 2001, 107(4):477-487.

74. Graber TE, Hebert-Seropian S, Khoutorsky A, David A, Yewdell JW, Lacaille JC, Sossin WS: Reactivation of stalled polyribosomes in synaptic plasticity. Proc Natl Acad Sci U S A 2013, 110(40):16205-16210.

75. Stoner R, Chow ML, Boyle MP, Sunkin SM, Mouton PR, Roy S, Wynshaw-Boris A, Colamarino SA, Lein ES, Courchesne E: Patches of disorganization in the neocortex of children with autism. N Engl J Med 2014, 370(13):1209-1219.

76. Buchan JR, Stansfield I: Halting a cellular production line: responses to ribosomal pausing during translation. Biol Cell 2007, 99(9):475-487.

77. Harigaya Y, Parker R: No-go decay: a quality control mechanism for RNA in translation. Wiley Interdiscip Rev RNA 2010, 1(1):132-141.

78. Rachidi M, Lopes C: Mental retardation in down syndrome: from gene dosage imbalance to molecular and cellular mechanisms. Neurosci Res 2007, 59(4):349-369.

79. Veitia RA, Birchler JA: Dominance and gene dosage balance in health and disease: why levels matter! J Pathol 2010, 220(2):174-185.

80. Arguello PA, Gogos JA: Genetic and cognitive windows into circuit mechanisms of psychiatric disease. Trends Neurosci 2012, 35(1):3-13.

81. Frydman J: Folding of newly translated proteins in vivo: the role of molecular chaperones. Annu Rev Biochem 2001, 70:603-647.

82. Hartl FU, Hayer-Hartl M: Molecular chaperones in the cytosol: from nascent chain to folded protein. Science 2002, 295(5561):1852-1858.

83. Willmund F, del Alamo M, Pechmann S, Chen T, Albanese V, Dammer EB, Peng J, Frydman J: The cotranslational function of ribosome-associated Hsp70 in eukaryotic protein homeostasis. Cell 2013, 152(1-2):196-209.

84. Hasday JD, Singh IS: Fever and the heat shock response: distinct, partially overlapping processes. Cell Stress Chaperones 2000, 5(5):471-480.

85. Atladottir HO, Henriksen TB, Schendel DE, Parner ET: Autism after infection, febrile episodes, and antibiotic use during pregnancy: an exploratory study. Pediatrics 2012, 130(6):e1447-e1454

86. Zerbo O, losif AM, Walker C, Ozonoff S, Hansen RL, Hertz-Picciotto I: Is maternal influenza or fever during pregnancy associated with autism or developmental delays? Results from the CHARGE (CHildhood autism risks from genetics and environment) study. J Autism Dev Disord 2013, 43(1):25-33.

87. Rajdev S, Sharp FR: Stress proteins as molecular markers of neurotoxicity. Toxicol Pathol 2000, 28(1):105-112.

88. El-Ansary AK, Ben Bacha A, Kotb M: Etiology of autistic features: the persisting neurotoxic effects of propionic acid. J Neuroinflammation 2012. $9(1): 74$.

89. Thomas RH, Foley KA, Mepham JR, Tichenoff $L$, Possmayer F, MacFabe DF: Altered brain phospholipid and acylcarnitine profiles in propionic acid infused rodents: further development of a potential model of autism spectrum disorders. J Neurochem 2010, 113(2):515-529.

90. Barrett MJ, Alones V, Wang KX, Phan L, Swerdlow RH: Mitochondria-derived oxidative stress induces a heat shock protein response. J Neurosci Res 2004, 78(3):420-429.

91. Roullet Fl, Lai JK, Foster JA: In utero exposure to valproic acid and autism-a current review of clinical and animal studies. Neurotoxicol Teratol 2013, 36:47-56.

92. Christensen J, Gronborg TK, Sorensen MJ, Schendel D, Parner ET, Pedersen $\mathrm{LH}$, Vestergaard M: Prenatal valproate exposure and risk of autism spectrum disorders and childhood autism. Jama 2013, 309(16):1696-1703.

93. Marinova Z, Ren M, Wendland JR, Leng Y, Liang MH, Yasuda S, Leeds $P$, Chuang DM: Valproic acid induces functional heat-shock protein 70 via class I histone deacetylase inhibition in cortical neurons: a potential role of Sp1 acetylation. J Neurochem 2009, 111(4):976-987.

94. Rossignol DA, Genuis SJ, Frye RE: Environmental toxicants and autism spectrum disorders: a systematic review. Trans/ Psychiatry 2014, 4:e360.

95. Freitag CM: The genetics of autistic disorders and its clinical relevance: a review of the literature. Mol Psychiatry 2007, 12(1):2-22.

96. Buizer-Voskamp JE, Franke L, Staal WG, van Daalen E, Kemner C, Ophoff RA, Vorstman JA, van Engeland H, Wijmenga C: Systematic genotypephenotype analysis of autism susceptibility loci implicates additional symptoms to co-occur with autism. Eur J Hum Genet 2010, 18(5):588-595.

97. El-Fishawy P, State MW: The genetics of autism: key issues, recent findings, and clinical implications. Psychiatr Clin North Am 2010, 33(1):83-105.

98. Hussman JP, Chung RH, Griswold AJ, Jaworski JM, Salyakina D, Ma D, Konidari I, Whitehead PL, Vance JM, Martin ER, Cuccaro ML, Gilbert JR, 
Haines JL, Pericak-Vance MA: A noise-reduction GWAS analysis implicates altered regulation of neurite outgrowth and guidance in autism. $\mathrm{Mol}$ Autism 2011, 2(1):1.

99. Rogozin IB, Pavlov YI: Theoretical analysis of mutation hotspots and their DNA sequence context specificity. Mutat Res 2003, 544(1):65-85.

100. McFarland CD, Korolev KS, Kryukov GV, Sunyaev SR, Mirny LA: Impact of deleterious passenger mutations on cancer progression. Proc Natl Acad Sci U S A 2013, 110(8):2910-2915.

101. Stamatoyannopoulos JA, Adzhubei I, Thurman RE, Kryukov GV, Mirkin SM, Sunyaev SR: Human mutation rate associated with DNA replication timing. Nat Genet 2009, 41(4):393-395.

102. Xu B, Roos JL, Dexheimer P, Boone B, Plummer B, Levy S, Gogos JA, Karayiorgou M: Exome sequencing supports a de novo mutational paradigm for schizophrenia. Nat Genet 2011, 43(9):864-868.

103. Xu B, lonita-Laza I, Roos JL, Boone B, Woodrick S, Sun Y, Levy S, Gogos JA, Karayiorgou M: De novo gene mutations highlight patterns of genetic and neural complexity in schizophrenia. Nat Genet 2012, 44(12):1365-1369.

104. Ayoub MA, Angelicheva D, Vile D, Chandler D, Morar B, Cavanaugh JA Visscher PM, Jablensky A, Pfleger KD, Kalaydjieva L: Deleterious GRM1 mutations in schizophrenia. PLoS One 2012, 7(3):e32849.

105. Courchesne E, Mouton PR, Calhoun ME, Semendeferi K, Ahrens-Barbeau C, Hallet MJ, Barnes CC, Pierce K: Neuron number and size in prefrontal cortex of children with autism. Jama 2011, 306(18):2001-2010.

106. Chow ML, Pramparo T, Winn ME, Barnes CC, Li HR, Weiss L, Fan JB, Murray S, April C, Belinson H, Fu XD, Wynshaw-Boris A, Schork NJ, Courchesne E: Age-dependent brain gene expression and copy number anomalies in autism suggest distinct pathological processes at young versus mature ages. PLoS Genet 2012, 8(3):e1002592.

107. Ecker C, Suckling J, Deoni SC, Lombardo MV, Bullmore ET, Baron-Cohen S, Catani M, Jezzard P, Barnes A, Bailey AJ, Williams SC, Murphy DG: Brain anatomy and its relationship to behavior in adults with autism spectrum disorder: a multicenter magnetic resonance imaging study. Arch Gen Psychiatry 2012, 69(2):195-209.

108. Morgan JT, Chana G, Abramson I, Semendeferi K, Courchesne E, Everall IP: Abnormal microglial-neuronal spatial organization in the dorsolateral prefrontal cortex in autism. Brain Res 2012, 1456:72-81.

109. Duffy FH, Als H: A stable pattern of EEG spectral coherence distinguishes children with autism from neuro-typical controls - a large case control study. BMC Med 2012, 10:64.

110. Silverman $J$, Tolu SS, Barkan CL, Crawley JN: Repetitive self-grooming behavior in the BTBR mouse model of autism is blocked by the mGluR5 antagonist MPEP. Neuropsychopharmacology 2010, 35(4):976-989.

111. Silverman JL, Smith DG, Rizzo SJ, Karras MN, Turner SM, Tolu SS, Bryce DK, Smith DL, Fonseca K, Ring RH, Crawley JN: Negative allosteric modulation of the mGluR5 receptor reduces repetitive behaviors and rescues social deficits in mouse models of autism. Sci Transl Med 2012, 4(131):131 ra151.

112. Michalon A, Sidorov M, Ballard TM, Ozmen L, Spooren W, Wettstein JG, Jaeschke G, Bear MF, Lindemann L: Chronic pharmacological mGlu5 inhibition corrects fragile $X$ in adult mice. Neuron 2012, 74(1):49-56.

113. Harrison C: Neurodevelopmental disorders: glutamate blockers show benefit in models of autism spectrum disorders. Nat Rev Drug Discov 2012, 11(6):440-441.

114. Calvo PL, Brunati A, Spada M, Romagnoli R, Corso G, Parenti G, Rossi M, Baldi M, Carbonaro G, David E, Pucci A, Amoroso A, Salizzoni M: Liver transplantation in defects of cholesterol biosynthesis: the case of lathosterolosis. Am J Transplant 2014, 14(4):960-965.

115. Stannard JN, Horecker BL: The in vitro inhibition of cytochrome oxidase by azide and cyanide. J Biol Chem 1948, 172(2):599-608

116. Leary SC, Hill BC, Lyons CN, Carlson CG, Michaud D, Kraft CS, Ko K, Glerum DM, Moyes CD: Chronic treatment with azide in situ leads to an irreversible loss of cytochrome c oxidase activity via holoenzyme dissociation. J Biol Chem 2002, 277(13):11321-11328.

117. Martin W, White DG, Henderson AH: Endothelium-derived relaxing factor and atriopeptin II elevate cyclic GMP levels in pig aortic endothelia cells. Br J Pharmacol 1988, 93(1):229-239.

118. Ceman S, O'Donnell WT, Reed M, Patton S, Pohl J, Warren ST: Phosphorylation influences the translation state of FMRP-associated polyribosomes. Hum Mol Genet 2003, 12(24):3295-3305.

119. Betterton EA: Environmental fate of sodium azide derived from automobile airbags. Crit Rev Environ Sci Technol 2003, 33:423-458.
120. Peca J, Feliciano C, Ting JT, Wang W, Wells MF, Venkatraman TN, Lascola CD, Fu Z, Feng G: Shank3 mutant mice display autistic-like behaviours and striatal dysfunction. Nature 2011, 472(7344):437-442

121. Spooren W, Lindemann L, Ghosh A, Santarelli L: Synapse dysfunction in autism: a molecular medicine approach to drug discovery in neurodevelopmental disorders. Trends Pharmacol Sci 2012, 33(12):669-684.

122. Ghosh A, Michalon A, Lindemann L, Fontoura P, Santarelli L: Drug discovery for autism spectrum disorder: challenges and opportunities. Nat Rev Drug Discov 2013, 12(10):777-790.

123. Leblond CS, Heinrich J, Delorme R, Proepper C, Betancur C, Huguet G, Konyukh M, Chaste P, Ey E, Rastam M, Anckarsater H, Nygren G, Gillberg IC, Melke J, Toro R, Regnault B, Fauchereau F, Mercati O, Lemiere N, Skuse D, Poot M, Holt R, Monaco AP, Jarvela I, Kantojarvi K, Vanhala R, Curran S, Collier DA, Bolton P, Chiocchetti A: Genetic and functional analyses of SHANK2 mutations suggest a multiple hit model of autism spectrum disorders. PLoS Genet 2012, 8(2):e1002521

124. Lada AG, Stepchenkova El, Waisertreiger IS, Noskov VN, Dhar A, Eudy JD, Boissy RJ, Hirano M, Rogozin IB, Pavlov YI: Genome-wide mutation avalanches induced in diploid yeast cells by a base analog or an APOBEC deaminase. PLoS Genet 2013, 9(9):e1003736.

doi:10.1186/1745-6150-9-16

Cite this article as: Poliakov et al:: Impairment of translation in neurons as a putative causative factor for autism. Biology Direct 2014 9:16.

\section{Submit your next manuscript to BioMed Central and take full advantage of:}

- Convenient online submission

- Thorough peer review

- No space constraints or color figure charges

- Immediate publication on acceptance

- Inclusion in PubMed, CAS, Scopus and Google Scholar

- Research which is freely available for redistribution 